\title{
The challenges and implications of assessing groundwater recharge: A case study - northern Sandveld, Western Cape, South Africa
}

\author{
Julian Conrad ${ }^{1 *}$, Jaco $\mathrm{Nel}^{2}$ and Johan Wentzel ${ }^{2}$ \\ ${ }^{1}$ GEOSS - Geohydrological and Spatial Solutions, Innovation Centre, Techno Park, Stellenbosch, 7600. \\ ${ }^{2}$ DWAF - Department of Water Affairs and Forestry, Pretoria.
}

\begin{abstract}
The Department of Water Affairs and Forestry (DWAF) is currently carrying out detailed hydrogeological studies within the northern Sandveld area, Western Cape, South Africa. In addition, preliminary studies funded by DWAF, have also been carried out in the area assessing hydrological, ecological and botanical components. The area is receiving much attention due to its environmental uniqueness (part of the area is a Ramsar site) and its significant groundwater resources, which are being utilised for agricultural purposes and municipal water supply. In certain areas this groundwater abstraction is impacting on surface water flows, groundwater and associated ecosystems.

In order to gain an understanding of the systems and their inter-relationships within the area, it is necessary to carry out water balance calculations. In carrying out such calculations, the quantification of the "input" component and associated temporal and spatial variability is important to address. With special emphasis on groundwater recharge, the area may be receiving both direct groundwater recharge, (as a consequence of precipitation), and distant groundwater inflow, via the large faults that transect the area, which may be importing groundwater from the inland recharge areas (i.e. the Cederberg Mountains).

Earlier groundwater recharge studies within the area and in geologically similar settings indicate a wide range in recharge values. With special reference to the primary aquifers, earlier conservative recharge values indicate $8 \%$ recharge, with values as high as $15 \%$ being obtained. The current study indicates direct recharge values in the region of 0.2 to $3.4 \%$. Assessment of water balance calculations indicate these recharge values are more realistic. The groundwater recharge quantification has huge significance for the Resource Directed Measures that are also being carried out in the area, in line with the requirements of the South African National Water Act of 1998. The Resource Directed Measures are aimed at ensuring water resource use and development is balanced by protection measures thereby guaranteeing the sustainable use of the resource.
\end{abstract}

\section{Introduction}

In order to optimally manage a groundwater resource that is being utilised, it is highly beneficial to carry out water balance calculations. One of the components of the water balance equation that needs to be determined is the rate of groundwater input. This input can be subdivided into three main components, namely: direct (vertical) recharge; recharge from river flow; and lateral inflow. For the study being carried out it is particularly important that the inputs be accurately determined.

The study area is located in the northern Sandveld, Western Cape, South Africa (see Fig. 1). The main reason for the area being studied is that it is a low rainfall area where significant groundwater abstraction occurs for both municipal and agriculture purposes. In addition, sensitive and important ecosystems in the area are showing varying degrees of impact. The objective of these studies is to understand the environmental linkages with surface and groundwater, and impacts resulting from groundwater use so management measures can be designed and implemented to ensure ongoing sustainable development of the area.

This paper was originally presented at the 2004 Water Institute of South Africa (WISA) Biennial Conference, Cape Town, South Africa, 2-6 May 2004.

* To whom all correspondence should be addressed.

苗+2721 880 1079; fax: +2721 880-1164 ;

e-mail: julian@geoss.co.za
It is particularly important to define groundwater inputs and especially direct recharge as significant economic benefit is being derived from groundwater usage by the agricultural sector, whilst the fragile ecosystems within the area are also very groundwater dependent and showing signs of being stressed and significantly impacted. Thus a balance needs to be sought between resource utilisation and ecological protection. De Vries and Simmers (2002) state that the quantification of groundwater recharge is a prerequisite for efficient and sustainable groundwater resource management in arid regions. They also state that recharge is defined in the general sense as the downward flow of water reaching the water table, forming an addition to the groundwater reservoir.

This paper discusses the main challenges associated with determining vertical groundwater recharge in an arid to semi-arid environment.

\section{Background information}

There are many references in international literature stating that groundwater recharge is one of the most difficult components of the hydrologic budget to quantify (Stephens and Knowlton, 1986; Jackson and Rushton, 1987; Cook and Kilty, 1992; and Stone et al., 2001). There is an increased difficulty in dealing with arid regions because of the variability of recharge with respect to time and space that is characteristic of arid areas (Verma, 1979; Yair and Lavee, 1985 and Simmers, 1988).

Natural recharge to an aquifer in an arid region may occur by various mechanisms, such as infiltration from the beds of ephem- 


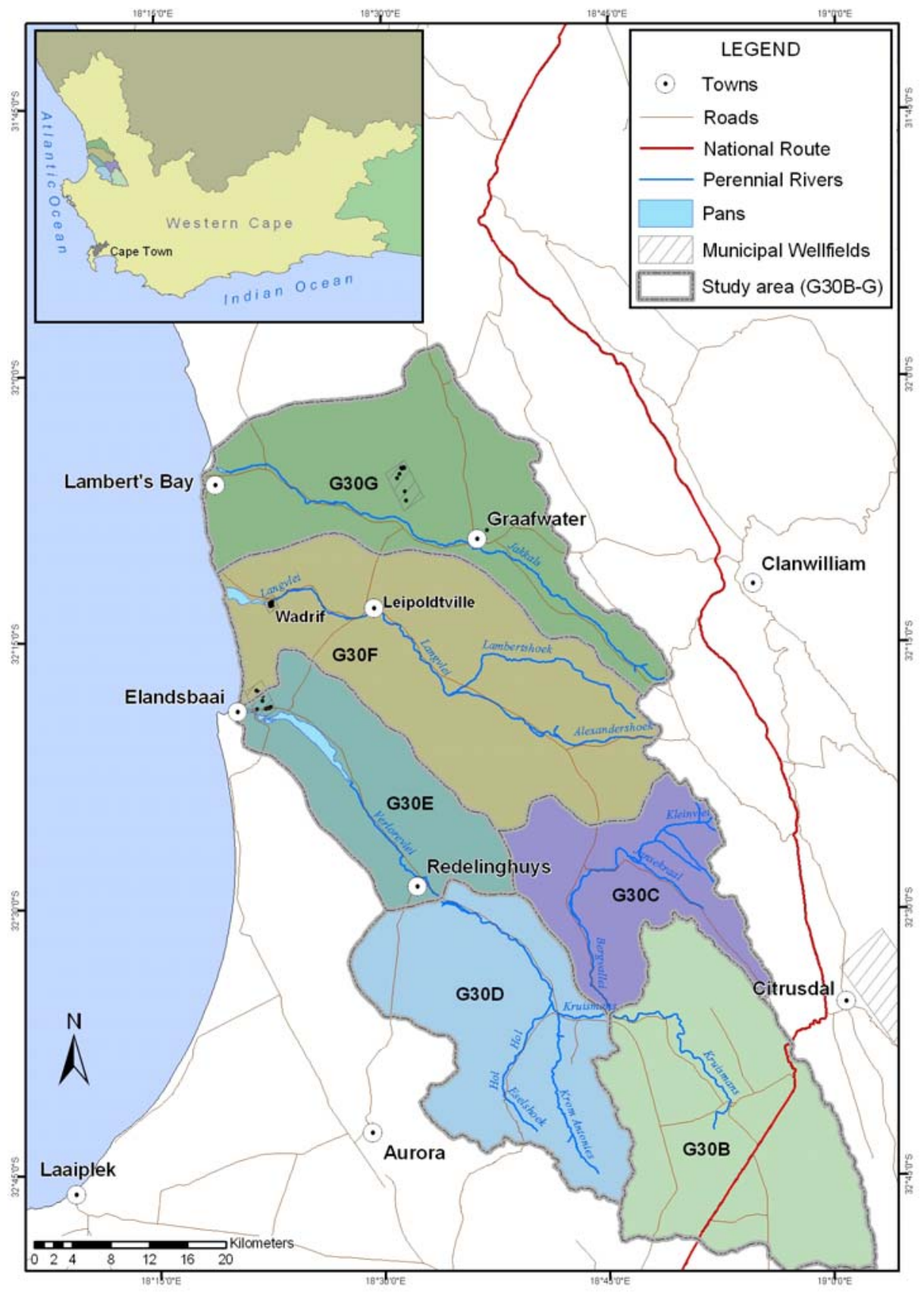

Figure 1

The study area, situated on the west coast of South Africa

With regard to groundwater recharge studies carried out on the South African west coast in the primary aquifers, a number of recharge values have been calculated. For the Atlantis area, Vandoolaeghe and Bertram (1982) used the water balance method to calculate a recharge rate of $26 \%$ of the rainfall (380 mm/a). Bredenkamp and Vandoolaeghe (1982) calculated a recharge rate of $25 \%$ (rainfall of $380 \mathrm{~mm}$ pa) also using a water balance method. They felt that a rate of 30 to $35 \%$ was not impossible. Bredenkamp (1982) modelled conditions at Atlantis and came up with a recharge rate of $21 \%$ of a total rainfall of $350 \mathrm{~mm}$ pa.

Timmerman (1985) working between the Berg River and Elands Bay estimated a recharge rate of $15 \%$ in an area where the rainfall varies between 200 and $316 \mathrm{~mm}$ pa. While investigating the Lower Berg River area, Timmerman (1985) once again suggested 15\% as the recharge rate (rainfall varies between 200 and $380 \mathrm{~mm}$ pa). In the Graafwater area (rainfall of 250 mm pa) Timmerman (1986) assumed a "conservative" recharge rate of $8 \%$. In the investigation at Strandfontein, Timmerman (1988) adopted a different approach - he stated that recharge would not occur on a yearly basis, but only sporadically. He suggested that recharge might only occur every 10 years, although a figure of 20 years would not be impossible.

At Elands Bay (rainfall of 196 $\mathrm{mm} / \mathrm{a}$ ) groundwater abstraction is being monitored. Jolly (1992) states that during the period 1989 to 1992 water levels have not dropped at all. Abstraction must therefore equal recharge. Calculations suggest a recharge rate of $12 \%$ per annum. This figure includes some

eral rivers (Moench and Kisiel, 1970; Besbes et al., 1978; Abdulrazzak, 1983; Dillon and Liggett, 1983; Lloyd, 1986; Walters, 1990; Sorman and Abdulrazzak, 1993), subsurface drainage from mountain areas through the alluvial material of valley beds (Khazaei, 1999) and the direct entrance of rainfall into the alluvial material of the lower plains (Dincer et al., 1974). In order to develop a successful recharge estimation approach for a region, the effects of all the mechanisms must be taken into account. To achieve this objective, Miles and Rushton (1983) and Simmers (1989) recommend a total catchment water balance approach. In this method all the factors affecting the recharge in the catchment, such as precipitation, evaporation, surface runoff, interflow, groundwater inflow and outflow, are incorporated (Senarath and Rushton, 1984). horizontal inflow, although how much is conjecture (Jolly, 1992).

Gerber (1980) modelled the water balance on the Cape Flats aquifer (rainfall of between 600 and $750 \mathrm{~mm} / \mathrm{a}$ ) and calculated a recharge figure of $40 \%$ for the dune area, although he did concede that this value did not take into account evapotranspiration of water that had already reached the groundwater level. Vandoolaeghe (1989) used a modelling exercise to calculate the exploitation potential of a hypothetical wellfield on the Cape Flats. During this exercise recharge was found to vary between 15 and 35\% of rainfall.

Timmerman (1985), working on the Grootwater Aquifer at Yzerfontein (rainfall of $340 \mathrm{~mm} / \mathrm{a}$ ), felt that $15 \%$ was the lower limit for recharge to the aquifer. Baron (1990) working on the same 
area selected a more conservative figure of $10 \%$.

Having presented all the above information it would appear that a vertical recharge figure of $8 \%$ is conservative for the primary aquifers of the west coast. Vegter (1995) indicated a value of $8 \%$ recharge for the Elands Bay area and $12 \%$ for the Lamberts Bay area.

However, there is literature that raises the possibility that the recharge percentage may be significantly less. Foster et al (1982) working on Ecca aquifers in the Kalahari (Botswana) calculated that during average rainfall years $(450 \mathrm{~mm} / \mathrm{a})$ no groundwater recharge would occur in areas where the soil/ sand cover was deeper that $4 \mathrm{~m}$. The rainfall would be stored in the sands and then evapotranspirated. Recharge would only occur in areas where the soil cover was thin or non-existent. Working in the same area, Mazor (1982) however, refutes Foster etal(1982). Mazor(1982) maintains that water level measurements and elevated tritium values prove that recharge does take place, although he ascertains that this is only in above-average rainfall years. He felt that preferential recharge zones exist within the sand cover, and recharge would occur, but with a time lag of up to four months, dependant on the sand thickness.

\section{Geological and hydrogeological setting of the study area}

\section{Geology}

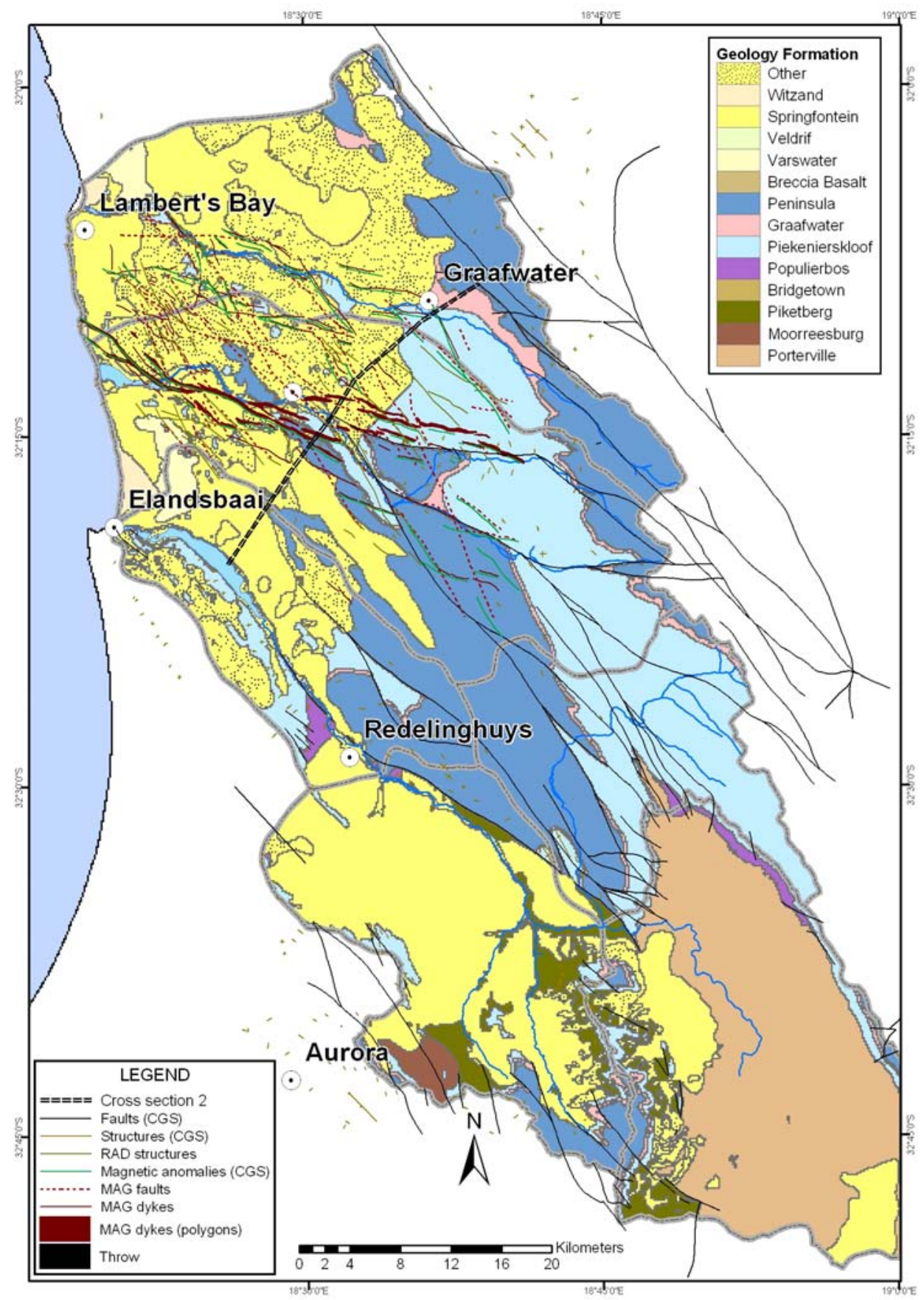

Figure 2

The main geological formations and structural features within the study area
Basement rocks of the Malmesbury Group, Gariep Supergroup and Cape Supergroup underlie the Sandveld area. Rocks of the Malmesbury Group and Gariep Supergroup are primarily soft, easy weathering argillaceous rocks, whilst rocks of the Cape Supergroup form the Cederberg mountain ranges on the eastern fringe of the Sandveld. Thick quartzose sandstones of the Table Mountain Group dominate the Cape Supergroup. Cenozoic deposits extensively cover the coastal plain.

The area has undergone a series of deformation events, resulting in the structural geology of the area having a NW-SE structural grain. The Sandveld is situated within the western branch of the Cape Fold Belt. Faults formed during the Mesozoic break-up of Gondwana have a similar orientation, but include a subsidiary
WNW-ESE trend of fractures that were subsequently intruded by dolerite to form regional dykes. Most of the geophysical anomalies found during an airborne study may be explained in terms of known structural fabrics. However, this work revealed major, hitherto undiscovered faults and dykes that occur beneath the sand cover in several places (see Fig. 2).

Rifting of the Atlantic margin and subsequent drifting were followed by continuous erosion of the rock superstructure from about 120 Ma ago to the present. Several fluctuations of sea level during middle and late Cenozoic times produced the lowermost of the Cenozoic deposits in the Sandveld. Extensive Quaternary sand deposits in turn cover these deposits.

Recently the Council of Geoscience reviewed the 1:250 000 

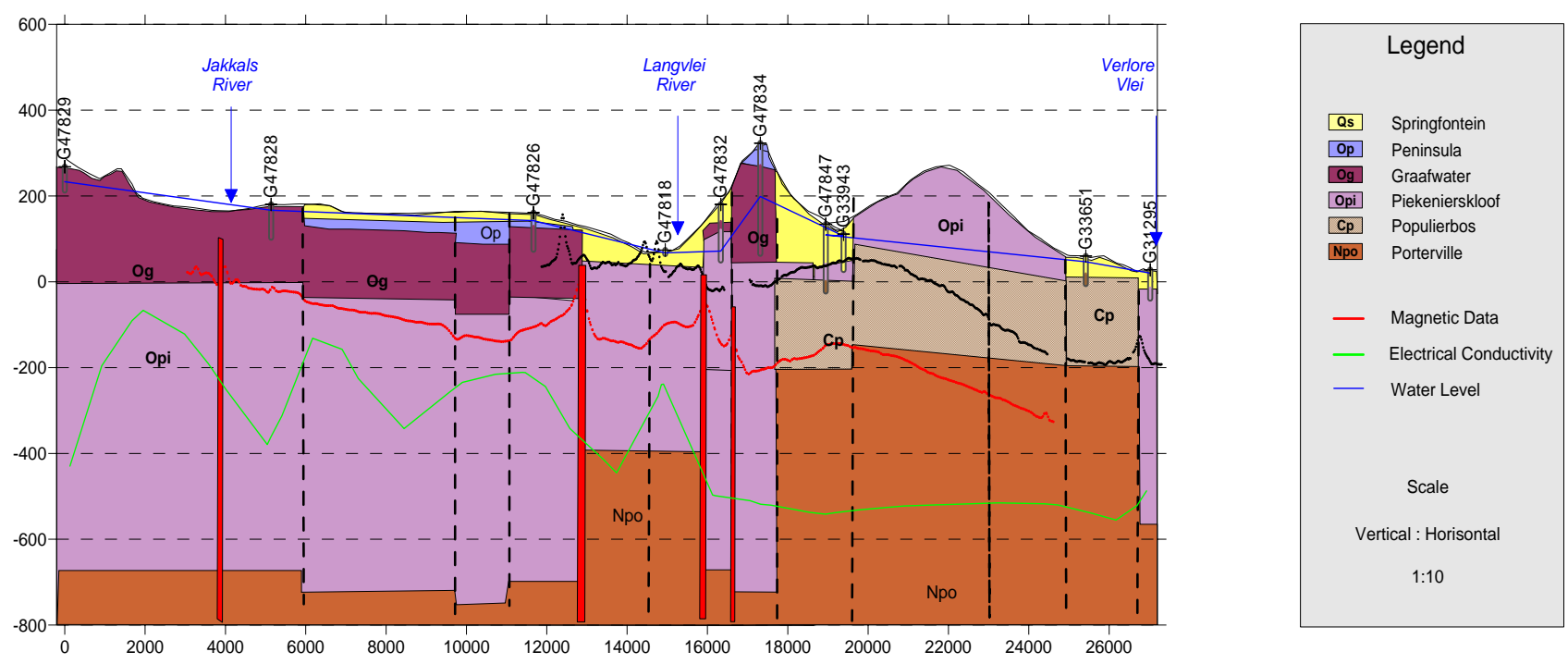

Figure 3

Hydrogeological cross-section, across the central portion of the study area (DWAF, 2004). Refer to Figure 2 for the section line.

geological mapping carried out in the area. Particular attention was given to geological structures and the production of geological cross sections (De Beer, 2003). Currently the Council for Geoscience is mapping the geology of the Sandveld area at a scale of 1:50 000.

\section{Hydrogeology}

The area comprises both unconsolidated primary and fracturedrock secondary aquifers. The primary aquifer is located on the western or coastal side of the study area. The aquifer comprises coarse grained and clean sand, and is typically high yielding. The aquifer thickness varies considerably and is controlled to some degree by palaeotopography. The groundwater table is typically shallow throughout the area and is also vulnerable to contamination. The primary aquifer is the main aquifer used for agricultural and domestic water supply purposes. Groundwater quality of the primary aquifer varies significantly. Salinity increases toward the coast, but groundwater is still used for agricultural purposes along the coastal zone. In general, groundwater levels mimic surface topography, but groundwater divides are not coincident with surface water divides (i.e. catchment boundaries). The general groundwater flow direction is westwards toward the coast.

The secondary aquifer is significant throughout the area. Structural features such as fault planes, weathered zones and bedding surfaces largely control groundwater flow in the aquifer. The secondary aquifer extends to the west beneath the primary aquifer. There is good connectivity between the primary and secondary aquifer. In general, the piezometric head of the secondary aquifer is higher than the water table in the secondary aquifer, suggesting discharge from the secondary aquifer into the primary aquifer. High borehole yields are obtained from well-sited boreholes and, in general, groundwater quality is good. The secondary aquifer is also used to supply groundwater for irrigation purposes.

There is seasonal interaction between surface water bodies and groundwater, although river flows during the hot, dry summer months become negligible. A number of springs are found throughout the area.

\section{Conceptual flow model}

The higher lying mountainous regions, occurring in the inland (eastern) portion of the study area, are the main groundwater recharge zones for the area. The high hydraulic head within the recharge zone then drives this recharge water through the bedrock toward the coast. Within the bedrock there is block faulting and fracturing. Groundwater flow in the bedrock preferentially occurs along some of these faults, however there is also flow within the fractured rock matrix. A cross-section trending perpendicular to the main structural trend of the area (northwest/southeast) is shown in Fig. 3 and the block-faulted nature of the area is apparent (DWAF, 2004). Fault depths, widths and degree of weathering are highly variable, and associated flow rates are thus also variable. The groundwater occurring within the primary aquifer is mainly derived from the underlying faults. Very little groundwater in the primary aquifer is derived from direct rainfall, due to the low rainfall amounts, high soil temperatures, and low soil moisture contents. In addition, piezometric levels within the secondary aquifer are shallower than water table levels in the primary aquifer and the isotopic composition of water within the primary aquifer is similar to that of inland rainfall.

\section{Groundwater recharge results}

A number of methods have been formulated for estimating groundwater recharge, such as direct measurement, Darcian approaches, tracer techniques, isotope dating, chloride mass-balance equations, analysis of baseflow hydrographs and spring discharges, water-table fluctuations, numerical modelling, water budgeting, etc. Information about these methods is given in Gee and Hillel (1988); Simmers (1988, 1997); Sharma (1989); Lerner et al. (1990); Allison et al (1994); Stephens (1994, 1996); Bredenkamp et al. (1995); Lerner (1997); De Vries and Simmers (2002); and Scanlon et al. (2002). Examples of relatively low-cost investigations at regional scales are provided by Adar et al. (1988); Gieske and De Vries (1990); Athavale et al. (1992); Edmunds and Gaye (1994); Kennett-Smith et al. (1994); Leaney and Herczeg (1995); Sukhija et al., (1996); Birkley et al. (1998); and Rangarajan and 
Athavale (2000). Choosing an appropriate technique for a particular site is not straightforward (Scanlon et al., 2002), and depends on several factors, including field constraints and availability of field data. However, techniques based on groundwater levels (water-table fluctuations) are among the most widely applied methods for estimating recharge rates (Healy and Cook, 2002). These methods are based on the premise that rises in groundwater levels in unconfined aquifers are due to recharge water arriving at the water table (Scanlon et al., 2002).

\section{Chloride mass-balance method}

From the work of DWAF (2004) three main zones are delineated based on the chloride mass balance method. The upper catchment receives about $500 \mathrm{~mm}$ rainfall of which $130 \mathrm{~mm}$ is predicted to reach groundwater (28\%). The recharge zone at the foot of the mountains is expected to receive between 250 and $300 \mathrm{~mm}$ rainfall, with about $15 \mathrm{~mm}$ reaching groundwater (5\%). The rest of the catchment receives about $200 \mathrm{~mm}$ rainfall of which not more than $2 \mathrm{~mm}$ replenishes groundwater (1\%). Groundwater level contour characteristics were used to confirm and refine the areas of groundwater recharge. The low recharge values obtained in the coastal area were also supported by anecdotal and empirical observations made by farmers active in the area (DWAF, 2004).

\section{GIS modelling}

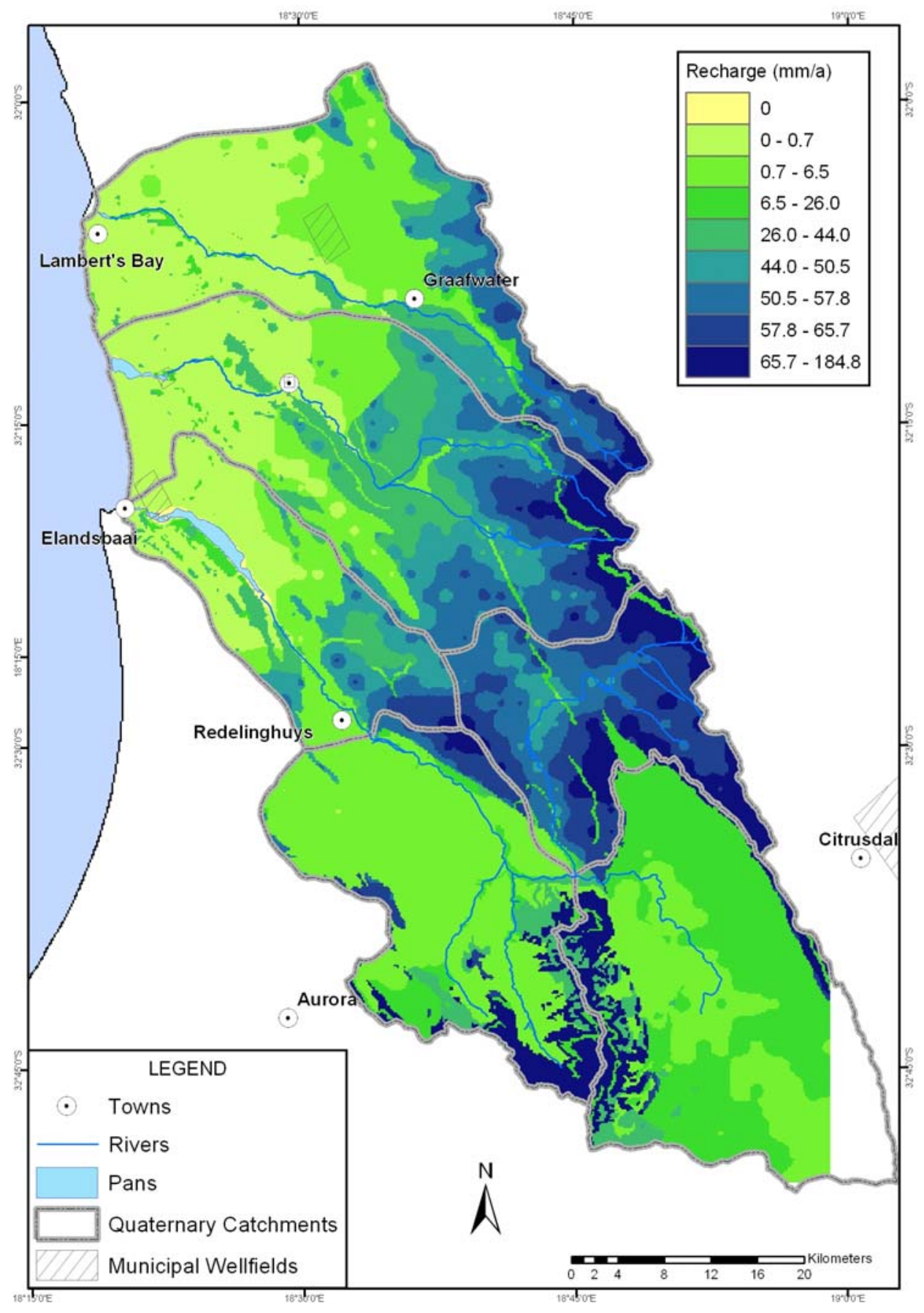

Figure 4

Groundwater recharge distribution across the study area
In order to address the significant spatial variability of groundwater recharge occurring throughout the area, a GIS based approach was used to determine groundwater recharge distribution. Many factors were considered and an approach similar to that outlined in Conrad et al. (2003) considered. After discussions and testing it was decided to simplify the approach and only two factors were taken into account, namely: lithology and rainfall distribution. Based on available literature recharge percentages were assigned to the different lithological units and these percentages applied to the mean annual rainfall grid in the area. The results from the spatial modelling are shown in Fig. 4. The values and distribution obtained are similar to the modelling results obtained by Umvoto-SRK (2000).

\section{Recharge assessments - point data}

A focused effort is currently being made on the collection of time series data of groundwater levels and rainfall. In due course a significant database will be available of groundwater and rainfall time series data. However, currently time series data is mainly available for the municipal supply wellfields within the area. An analysis of this data was carried out using a number of methods, including the chloride method, the Saturated Volume Fluctuation (SVF) Method, the Cumulative Rainfall Departure (CRD) Method and the Extended model for Aquifer Recharge and soil moisture 
TABLE 1

Point recharge estimates based on boreholes with water level time series data and compared to the GIS modelled results

\begin{tabular}{|l|c|c|c|c|c|c|c|c|c|c|}
\hline & \multicolumn{2}{|c|}{ Cl method } & \multicolumn{2}{c|}{ SVF } & \multicolumn{2}{c|}{ CRD } & \multicolumn{2}{c|}{ EARTH } & \multicolumn{2}{c|}{ GIS } \\
\cline { 2 - 11 } & $\%$ & $\mathbf{m m} / \mathbf{a}$ & $\%$ & $\mathbf{m m / a}$ & $\%$ & $\mathbf{m m} / \mathbf{a}$ & $\%$ & $\mathbf{m m} / \mathbf{a}$ & $\%$ & $\mathbf{m m} / \mathbf{a}$ \\
\hline Graafwater wellfield & 1.2 & 2.9 & 1.7 & 4.3 & 1.8 & 4.6 & 3.4 & 8.5 & 0.4 & 1.0 \\
Wadrif wellfield & 1.0 & 1.5 & 1.5 & 2.3 & 1.4 & 2.1 & 0.9 & 1.4 & $\sim 0.3$ & 0.45 \\
Elands Bay wellfield & 0.9 & 1.8 & 2.0 & 4.3 & 1.8 & 3.8 & 0.5 & 1.1 & 0.3 & 0.65 \\
G33946 & 3.3 & 8.3 & 0.3 & 0.8 & 2.3 & 5.7 & 1.2 & 3.0 & 0.2 & 0.5 \\
\hline
\end{tabular}

Transport through the unsaturated Hardrock (EARTH) method. The point assessment results carried out on the boreholes with time series data are indicated in Table 1.

\section{Discussion}

Prior to the detailed hydrogeological studies being carried out in the Sandveld, recharge values for the primary aquifer within the study area were estimated to be conservatively $8 \%$. As a consequence of recent studies this value is considered to be high and direct recharge percentages in the region of 0.2 to $3.4 \%$ are considered to be more realistic. The results presented in this paper are preliminary and will be reassessed once longer period water level time series data becomes available. In addition, isotopic sampling of groundwater has occurred and the results, once obtained, will also be analysed. Additional recharge methods including base flow and spring discharge techniques will also be followed up. The direct recharge is only one of the components required for quantifying groundwater inflow into the study catchments and in parallel with the recharge assessments other assessments are being carried out to determine deep seated inflow and the interaction between surface water and groundwater. The accurate quantification of groundwater inflow is very important, particularly in the light of the requirements of the South African Water Act of 1998. The Water Act states that the total volume of the resource must be quantified and basic human needs and aquatic ecosystem requirements (called a Reserve) set aside from this total volume. Thereafter water can be allocated to other users such as municipalities, agricultural irrigators and industry (this study area has no international resource allocation obligations). Thus quantification of the total resource, including the Reserve, legal allocations and illegal usage, is necessary to ensure the sustainable utilisation of our scare water resources in South Africa.

\section{References}

ABDULRAZZAK MJ (1983) Recharge from an ephemeral stream following wetting front arrival to water table. Water Resour. Res. 19 (1) 194200.

ADAR EM, NEUMAN SP and WOOLHISER DA (1988) Estimation of spatial recharge distribution using environmental isotopes and hydrochemical data. J. Hydrol. 97 251-302.

ALLISON GB, GEE GW and TYLER SW (1994) Vadoze-zone techniques for estimating groundwater recharge in arid and semi-arid regions. Soil Sci. Soc. Am. J. 58 6-14.

ATHAVALE RN, RANGARAJAN R and MURALIDHARAN D (1992) Measurement of natural recharge in India. J. Geol. Soc. India 39 235244.

BARON (1990) Aquifer characteristics and recommended water allocations in the Grootwater Aquifer Unit, Yzerfontein Subterranean Gov- ernment Water Control Area. Directorate Geohydrology, Dept of Water Affairs and Forestry, Technical Report Gh3715, Cape Town.

BESBES M, DELHOMME JP and DE MARSILY G (1978) Estimating recharge from ephemera] streams in arid regions: A case study at Kairouan, Tunisia. Water Resour. Res. 14 281-290.

BIRKLEY P, TORRES ROTRIGUEZ V and GONZALEZ PE (1998) The water balance for the basin of the valley of Mexico and implications for future water consumption. J. Hydrogeol. 6 (4) 500-517.

BREDENKAMP DB and VANDOOLAEGHE MAC (1982)Die Ontginbare Grondwater Potensiaal van die Atlantis Gebied. Gh Report \# 3227, Geohydrology, Cape Town.

BREDENKAMP DB (1982) Evaluering van die Waterpotensiaal van die Kussande by Atlantis Volgens ' $n$ Viskundige Model van die Grondwaterstelsel en Beramings van die Interferensie tussen Boorgate. Gh Report \# 3233, Geohydrology, Pretoria.

BREDENKAMP DB, BOTHA LJ, VAN TONDER GJ and VAN RENSBURG HJ (1995) Manual on Quantitative Estimation of Groundwater Recharge and Aquifer Storativity. Report TT 73/95. Water Research Commission, Pretoria. 419 pp.

CONRAD J, ADAMS J and TITUS R (2003) GIS based assessment of groundwater recharge in the fractured rocks of Namaqualand, South Africa. Groundwater in Fractured Rocks (2003) - Prague, Czech Republic, Krasny-Hrkal-Bruthans (eds). IAH Annual Congress,.

COOK PG and KILTY S (1992) A helicopter borne electromagnetic survey to delineate groundwater recharge rates. Water Resour Res.

DE BEER CH (2003) The Geology of the Sandveld Area between Lambert's Bay and Piketberg (Project 5510). Council for Geoscience, Western Cape Unit, Bellville. CGS Report No. 2003-0032.

DE VRIES JJ and SIMMERS I (2002) Groundwater recharge: An overview of processes and challenges. Hydrogeol. J. 10 (1) 5-17.

DILLON P and LIGGETT JA (1983) An ephemeral stream-aquifer interaction model. Water Resour. Res. 19 621-626.

DINCER T, AL-MUGRIN A and ZIMMERMANN U (1974) Study of the infiltration and recharge through sand dunes in arid zones with special reference to the stable isotopes and thermonuclear tritium. J. Hydrol. 23 79-87.

EDMUNDS WM and GAYE CB (1994) Estimating the variability of groundwater recharge in the Sahel using chloride. J. Hydrol. 56 47-59.

FOSTER SSD, BATH AH, FARR JL and LEWIS WJ (1980) The Likelihood of Active Groundwater Recharge in the Botswana Kalahari. J. Hydrol. 55.

GEE GW and HILLEL D (1988) Groundwater recharge in arid regions: review and critique of estimation methods. Hydrol. Proc. 2 255- 266.

GERBER A (1980) Final report on the Geohydrology of the Sand Deposits in the Cape Flats, CSIR, Pretoria.

GIESKE ASM and DE VRIES JJ (1990) Conceptual and computational aspects of the mixing cell method to determine groundwater recharge components. J. Hydrol. 121 277-292.

HEALY RW and COOK PG (2002) Using groundwater levels to estimate recharge. J. Hydrogeol. 10 (2) 91-109.

JACKSON D and RUSHTON KR (1987) Assessment of recharge components for a chalk aquifer unit. J. Hydrol. 92 1-15.

JOLLY J (1992) The Geohydrology of the Graafwater Government Subterranean Water Control Area. Gh \#3 778, Geohydrology, Cape Town. 
KENNETT-SMITH A, COOK PG and WALKER GR (1994) Factors affecting groundwater recharge following clearing in the south-western Murray Basin. J. Hydrol. 154 85-105.

KHAZAEI E (1999) A study of groundwater recharge in Zahedan Catchment an arid region of south eastern Iran. J. Appl. Hydrol. XII (4) $1-14$

LEANEY FW and HERCZEG AL (1995) Regional recharge to a Karst aquifer estimated from chemical and isotopic composition of diffuse and localized recharge. J. Hydrol. 164 363-387.

LERNER DN (1997) Groundwater recharge. In: Saether OM, De Caritat P (eds.) Geochemical Processes, Weathering and Groundwater Recharge in Catchments. A.A. Balkema, Rotterdam.

LLOYD JW (1986) A review of aridity and groundwater. Hydrol. Proc. 1 63-78.

MAZOR E (1982) Rain recharge in the Kalahari - A note on some approaches to the problem. J. Hydrol. 55.

MILES JC and RUSHTON KR (1983) A coupled surface water and groundwater catchment model. J. Hydrol. 62 159-177.

MOENCH AF and KISIEL CC (1970) Application of the convolution relation to estimating recharge from an ephemeral stream. Water Resour. Res. 6 (4) 1087-1094.

NEL J (2004) Gh 4000. Groundwater potential of the Langvlei Catchment. In preparation, DWAF.

RANGARAJAN R and ATHAVALE RN (2000) Annual replenishable groundwater potential of India - An estimate based on injected tritium studies. J. Hydrol. 234 38-53.

SCANLON BR, HEALY RH and COOK PG (2002) Choosing appropriate techniques for quantifying groundwater recharge. Hydrogeol. J. 10 (1) 18-39.

SENARATH DC and RUSHTON KR (1984) A routing technique for estimating groundwater recharge. Ground Water 22 (2) 142-147.

SHARMA ML (1989) Groundwater Recharge. AA Balkema, Rotter-dam.

SIMMERS I (1988) Estimation of natural groundwater recharge. NATO ASI Series C. Vol 222. Proc. of the NATO Advanced Research Workshop, Antalya, Turkey, March 1987. Reidel, Dordrecht, ed.

SIMMERS I (1989) Natural groundwater recharge estimation in semiarid zones: Some state-of-art observations. Proc. of the Sahel Forum, the State-of-Art of Hydrol. and Hydrogeol. in the Arid and Semi-Arid Areas of Africa, Oua-gadougou, Burkina Faso, February. 374-386.

SIMMERS I (1997) Recharge of Phreatic Aquifers in (Semi-)Arid Areas. AA Balkema, Rotterdam. 277 pp.

SIMMERS I (1997) Estimation of Natural Groundwater Recharge. Reidel, Boston, $510 \mathrm{pp}$.

SORMAN AU and ABDULRAZZAK MJ (1993) Infiltration-recharge through wadi beds in arid regions. Hydrol. Sci. J. 38i3 i; 173-186.

STEPHENS DB (1994) A perspective on diffuse natural recharge mechanisms in areas of low precipitation. Soil Sci. Soc. Am. J. 58 40-48.

STEPHENS DB (1996) Estimation of Infiltration and Recharge for Environmental Site Assessment. API Publ. 4643. Health and Environmental Sciences Department, Albuquerque, New Mexico.
STEPHENS DB and KNOWLTON R (1986) Soil water movement and recharge through and at a semi arid site in New Mexico. Water Resour. Res. 22 (6) 81-889.

STONE DB, MOOMAW CL and DAVIS CL (2001) Estimating recharge distribution by incorporating runoff from mountainous area in an alluvium basin in Great Basin Region of the Southwestern United States. Groundwater 39 (6) 807-818.

SUKHIJA BS, NAGABHUSHANAM P and REDDY DV (1996) Groundwater recharge in semi-arid regions of India: An overview of results obtained using tracers. J. Hydrogeol. 4 (3) 50-71.

TIMMERMAN LRA (1985) Possibilities for the development of groundwater from the Cenozoic sediments in the lower Berg River Region. Gh Report \# 3374, Geohydrology, Cape Town.

TIMMERMAN LRA (1985) Preliminary report on the Cenozoic sediments of part of the Coastal Plain between the Berg River and Eland's Bay. Gh Report \# 3370, Geohydrology, Cape Town.

TIMMERMAN LRA (1985) Preliminary report on the Geohydrology of the Grootwater Primary Aquifer unit between Yzerfontein and the Modder River. Gh Report \# 3372, Geohydrology, Cape Town.

TIMMERMANLRA (1986) Sandveld Region: Possibilities for the Development of a Groundwater Supply Scheme from a Primary Aquifer Northwest of Graafwater. Report Gh3471, Geohydrology, Cape Town.

TIMMERMAN LRA (1988) Exploration for Groundwater Resources near Strandfontein, Doringbaai and Papendorp. Gh Report \# 3511, Geohydrology, Pretoria.

UMVOTO-SRK (2000) Reconnaissance investigation into the development and utilization of the Table Mountain Group Artesian Groundwater, using the E10 catchment as a pilot study area.

VANDOOLAEGHE MAC and BERTRAM E (1982) Atlantis Grondwatersisteem: Herevaluasie van Versekerde Lewering. Gh Report \# 3222, Geohydrology, Cape Town.

VANDOOLAEGHE MAC (1989) The Cape Flats Groundwater Development Pilot Abstraction Scheme. Gh Report \# 3655, Geohydrology, Cape Town.

VEGTER JR (1995) An Explanation of a Set of National Groundwater Maps. Prepared for the Water Research Commission, Report Number TT 74/95, August.

VERMA RD (1979) A physical model of the rainfall-runoff relationship for semiarid lands. The hydrology of areas of low precipitation. Proceedings of the Canberra Symposium. December. Int. Assoc Hydrol. Sci. - Assoc. Int. Sci. Hydrol. 128 215-217.

WALTERS MO (1990) Transmission losses in arid regions. J. Hydraul. Div. Am. Soc. Civil Eng. 116 (1) 129138.

YAIR A and LAVEE H (1985) Runoff generation in arid and semiarid zones. In: Anderson MG and Burt TP (ed.) Hydrological Forecasting. Wiley. New York. 183-220. 